\title{
Management of Men with a Suspicion of Prostate Cancer after Negative Initial Prostate Biopsy Results
}

\author{
Sachi Yamamoto ${ }^{a}$ Mayuko Kato ${ }^{a}$ Yuusuke Tomiyama ${ }^{a}$ Yoshiyasu Amiya ${ }^{a}$ \\ Makoto Sasaki ${ }^{a}$ Takayuki Shima ${ }^{a}$ Noriyuki Suzuki ${ }^{a}$ Shino Murakamia \\ Hiroomi Nakatsu ${ }^{a}$ Jun Shimazaki ${ }^{b}$

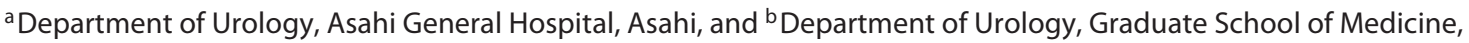 \\ Chiba University, Chiba, Japan
}

\section{Key Words}

Prostate cancer - Negative biopsy - PSA doubling time .

PSA velocity $\cdot$ Ratio of percent free PSA

\begin{abstract}
Introduction: For men with elevated prostate-specific antigen (PSA), appropriate management after negative prostate biopsy remains controversial. After determining PSA kinetics, subsequent follow-up was considered. Patients and Methods: A total of 115 cases with negative repeat biopsy were followed by evaluating PSA kinetics and ratio of percent free PSA (F/T) and by performing second repeat biopsy. Results: Eighteen cancer cases were diagnosed. Shorter PSA doubling times and faster velocities were found in cancer cases compared with cases without cancer. We observed a clear decrease in F/T among cancer cases. Conclusions: To avoid unnecessary repeat biopsies, cases with a suspicion of cancer after negative biopsy can be divided into two groups: one that requires additional biopsies and one with an average change in PSA of $<1 \mathrm{ng} / \mathrm{ml} /$ year and no change in $\mathrm{F} / \mathrm{T}$, which is recommended for surveillance as stable disease without biopsy over a specified time period.
\end{abstract}

(c) 2014 S. Karger AG, Basel

\begin{tabular}{ll}
\hline KARGER & $\begin{array}{l}\text { ( } 2014 \text { S. Karger AG, Basel } \\
0042-1138 / 14 / 0923-0258 \$ 39.50 / 0\end{array}$ \\
E-Mail karger@karger.com & This is an Open Access article licensed under the terms of the \\
www.karger.com/uin & $\begin{array}{l}\text { Creative Commons Attribution-NonCommercial 3.0 Un- } \\
\text { ported license (CC BY-NC) (www.karger.com/OA-license), } \\
\text { applicable to the online version of the article only. Distribu- } \\
\text { tion permitted for non-commercial purposes only. }\end{array}$
\end{tabular}

\section{Introduction}

Early prostate cancer detection is achieved by obtaining small tissue samples for histological examination by needle biopsy via the perineal or rectal routes. Candidates for this examination include men with elevated total serum prostate-specific antigen (PSA) in the presence or absence of an abnormal digital rectal examination finding. A negative result for the initial biopsy may affect the subsequent management of the candidates. Repeat biopsy after appropriate time intervals constitutes a general strategy, because more than one fourth of all prostate cancers are missed during the first biopsy [1]. A repeat biopsy is then planned, but the selection of suitable cases and the appropriate time period between biopsies remain controversial.

Several markers are significantly correlated with the detection of prostate cancerous tissues at repeat biopsy. These markers include initial PSA, PSA kinetics, the ratio of percent free PSA (F/T) and prostate volume [2]. However, individual markers do not identify cancerous tissues at a high rate, most likely because cancer and cancer-free cases have overlapping ranges of values for individual markers. Previously, we reported that men with a PSA doubling time exceeding 100 months did not have can-

Jun Shimazaki, MD

Department of Urology, Graduate School of Medicine

Chiba University, 1-8-1, Inohana, Chuo-ku

Chiba 260-8670 (Japan)

E-Mail shimajun@opal.famille.ne.jp 
cerous tissues in repeat biopsy [3]. This result suggests to select one group that may be observed more for a specified time period without aggressive examination including repeat biopsy. The present study aimed to reduce the number of unnecessary repeat biopsies in cases with gray zone or slightly elevated PSA values.

\section{Patients and Methods}

\section{Patients}

This study was approved by the Ethics Committee of Asahi General Hospital. Between 2004 and 2008, 2,380 cases who presented with 4-20 ng/ml of total PSA at a local health care examination asked the Asahi General Hospital to perform prostate biopsy regardless of any abnormal observations in the prostate glands, and cancer was detected in 1,002 cases (42\%). Of the 1,378 cancerfree cases, 193 men without advanced age or serious diseases who intended to undergo further examination were included in the surveillance group and underwent the first repeat biopsy after 1-3 years. Cancer was detected in 78 of 193 men (40\%). The remaining 115 negative cases underwent a second repeat biopsy 2 years later. The present study discusses these 115 cases.

The second repeat biopsies of the 115 men were performed via the perineal route with $\geq 12$ biopsy cores. Whole prostate volumes and transition zone (TZ) volumes were measured with an ultrasound apparatus (ALOKA, SSD-5500, Chiba, Japan). PSA density and PSA TZ density were calculated based on the total PSA level divided by the respective volumes. Cases with high-grade prostatic intraepithelial neoplasia or atypical small acinar proliferation were excluded from the study because these lesions are considered precancerous $[4,5]$.

\section{Measurement of PSA and PSA Kinetics}

Total and free PSA were assayed with the PSA Dainapack (Abbot, Chiba, Japan). To determine PSA doubling time and PSA velocity, three or more PSA values were assayed at an interval of 3 months or more. The points were depicted as $\ln$ PSA (ln 2/slope for doubling time) or PSA (linear regression for velocity) according to the least squares method and the values were obtained [6]. Differences in F/T were calculated by subtracting the value at each point from that at the initial biopsy.

Statistical Analyses

Mann-Whitney test, Student's t test and $\chi^{2}$ test were used, and $\mathrm{p} \leq 0.05$ was considered to be significant. All calculations were performed with the SPSS (IBM, Tokyo, Japan) and KaleidaGraph (Hulinks, Tokyo, Japan) software programs.

\section{Results}

The characteristics of the 115 cases at the first examination are shown in table 1 . These cases showed negative results in the initial and first repeat biopsies, and 18 cancerpositive patients $(16 \%)$ were identified at the second repeat biopsy. Cancerous tissues were revealed in 1-3 biopsy

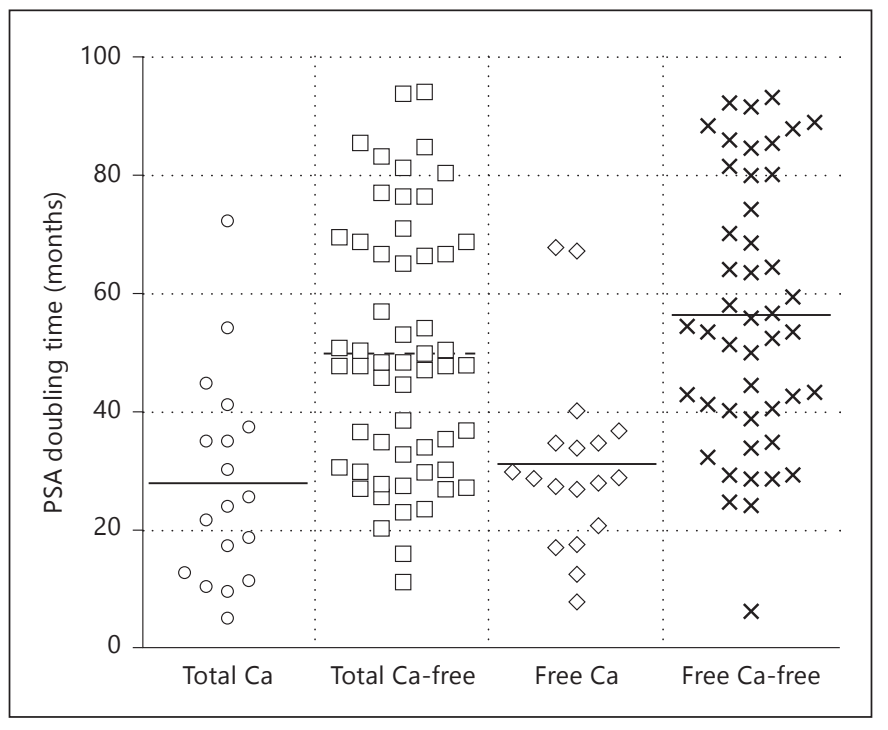

Fig. 1. Total and free PSA doubling times. $\mathrm{Ca}=$ Cancer group. Data over 100 months were excluded.

Table 1. Characteristics of individuals with presence or absence of cancer at the first examination

\begin{tabular}{lcll}
\hline & $\begin{array}{l}\text { Cancer } \\
(\mathrm{n}=18)\end{array}$ & $\begin{array}{l}\text { Cancer-free } \\
(\mathrm{n}=97)\end{array}$ & $\mathrm{p}$ \\
\hline Age, years & $68.3 \pm 5.6$ & $65.3 \pm 8.5$ & $\mathrm{~ns} *$ \\
Total PSA, ng/ml & $10.33 \pm 8.68$ & $7.86 \pm 5.93$ & $\mathrm{~ns}$ \\
Free PSA, ng/ml & $2.03 \pm 2.23$ & $1.61 \pm 1.46$ & $\mathrm{~ns}$ \\
Ratio of percent free PSA & $19.6 \pm 10.4$ & $20.6 \pm 8.7$ & $\mathrm{~ns}$ \\
Prostate volume, $\mathrm{ml}^{3}$ & $33.2 \pm 13.3$ & $42.3 \pm 19.4$ & $\mathrm{~ns}$ \\
Transition volume, $\mathrm{ml}^{3}$ & $17.7 \pm 12.9$ & $21.6 \pm 15.4$ & $\mathrm{~ns}$ \\
PSA density, $\mathrm{ng} / \mathrm{ml} / \mathrm{ml}^{3}$ & $0.37 \pm 0.39$ & $0.19 \pm 0.14$ & 0.001 \\
PSA TZ density*, $\mathrm{ng} / \mathrm{ml}^{3} / \mathrm{ml}^{3}$ & $0.90 \pm 1.10$ & $0.43 \pm 0.25$ & 0.0003 \\
\hline
\end{tabular}

* PSA transition zone density, ${ }^{* *}$ not significant.

cores with Gleason scores of 6 (23\%), 7 (66\%) and 8 (11\%), respectively. The clinical stages were $\mathrm{T} 1 \mathrm{c}(73 \%)$ and $\mathrm{T} 2$ (27\%). Subjects with and without cancer had similar total and free PSA values. A greater PSA density and PSA TZ density were observed in the cancer cases when compared with those without cancer, because slight prostate volume differences might have partially influenced the results.

PSA doubling times in excess of 100 months indicate almost no change in PSA levels during the observation time period, therefore the data of 13 cancer-free cases with values $>100$ months were omitted when comparing PSA doubling times. There were no cases over this cut-off value in the cancer group. The total and free PSA dou- 


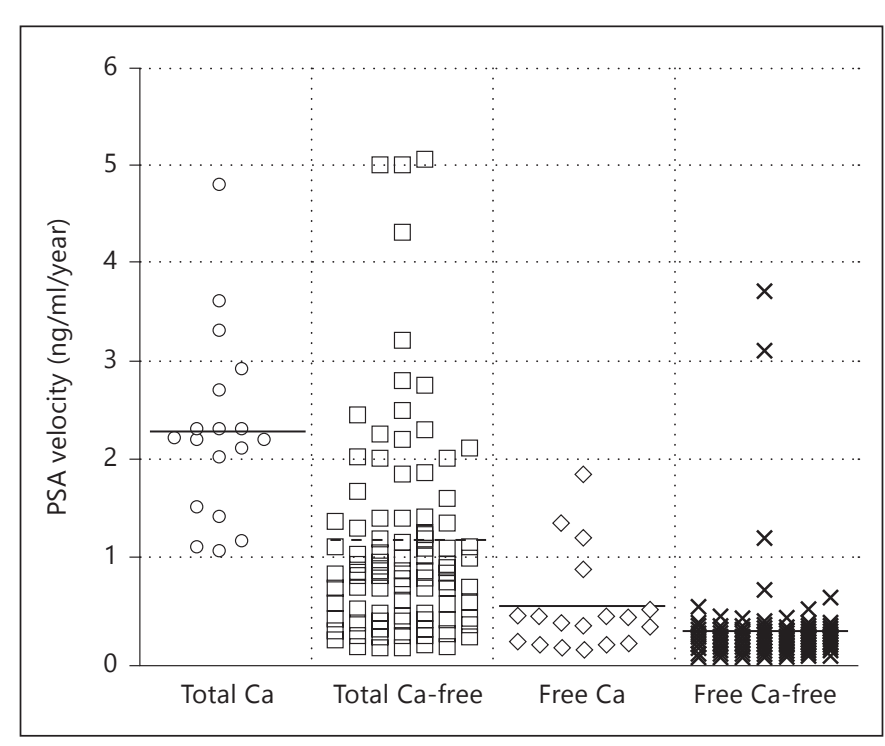

Fig. 2. PSA velocity. $\mathrm{Ca}=$ Cancer group.

Table 2. PSA doubling time, velocity and change in $\mathrm{F} / \mathrm{T}$

\begin{tabular}{lccl}
\hline & $\begin{array}{l}\text { Cancer } \\
(\mathrm{n}=18)\end{array}$ & $\begin{array}{l}\text { Cancer-free } \\
(\mathrm{n}=84)\end{array}$ & $\mathrm{p}$ \\
\hline Total PSA doubling time, months & $28.0 \pm 17.6$ & $49.9 \pm 21.5^{\mathrm{a}}$ & 0.0001 \\
Free PSA doubling time, months & $32.0 \pm 18.0$ & $56.5 \pm 22.6^{\mathrm{a}}$ & 0.0002 \\
Total PSA velocity, ng/ml/year & $2.2 \pm 1.1$ & $1.2 \pm 1.1^{\mathrm{a}}$ & 0.002 \\
Free PSA velocity, ng/ml/year & $0.5 \pm 0.5$ & $0.2 \pm 0.5^{\mathrm{a}}$ & $\mathrm{ns}$ \\
Decrease in F/T per yearb & $-1.83 \pm 2.43$ & $-0.43 \pm 1.92$ & 0.05 \\
\hline
\end{tabular}

${ }^{a}$ Data without increase are excluded. ${ }^{\mathrm{b}}$ Subtract each value from that at initial biopsy. Data show 100 times different ratio of F/T.

Table 3. Detection of cancer in cases with negative initial and first repeat biopsy

\begin{tabular}{|c|c|c|c|c|c|}
\hline \multirow{2}{*}{$\begin{array}{l}\text { Cases } \\
\text { No. }\end{array}$} & \multirow{2}{*}{$\begin{array}{l}\text { Average change } \\
\text { in total PSA, } \\
\text { ng/ml/year }\end{array}$} & \multicolumn{3}{|c|}{ Change in $\mathrm{F} / \mathrm{T}$} & \multirow{2}{*}{$\begin{array}{l}\text { Percent o } \\
\text { cancer }\end{array}$} \\
\hline & & decrease & no change & increase & \\
\hline 54 & $\leq 1$ & 0 & 0 & 1 & 2 \\
\hline 20 & $>1-2$ & 5 & 0 & 0 & 25 \\
\hline 28 & $>2$ & 12 & 0 & 0 & 43 \\
\hline
\end{tabular}

bling times showed decreasing trends in the cancer group compared with the cancer-free group (fig. 1). Similarly the trends for PSA velocity also differed between groups, as subjects with cancer tended to have a faster velocity (fig. 2). The PSA parameters are shown in table 2. In the

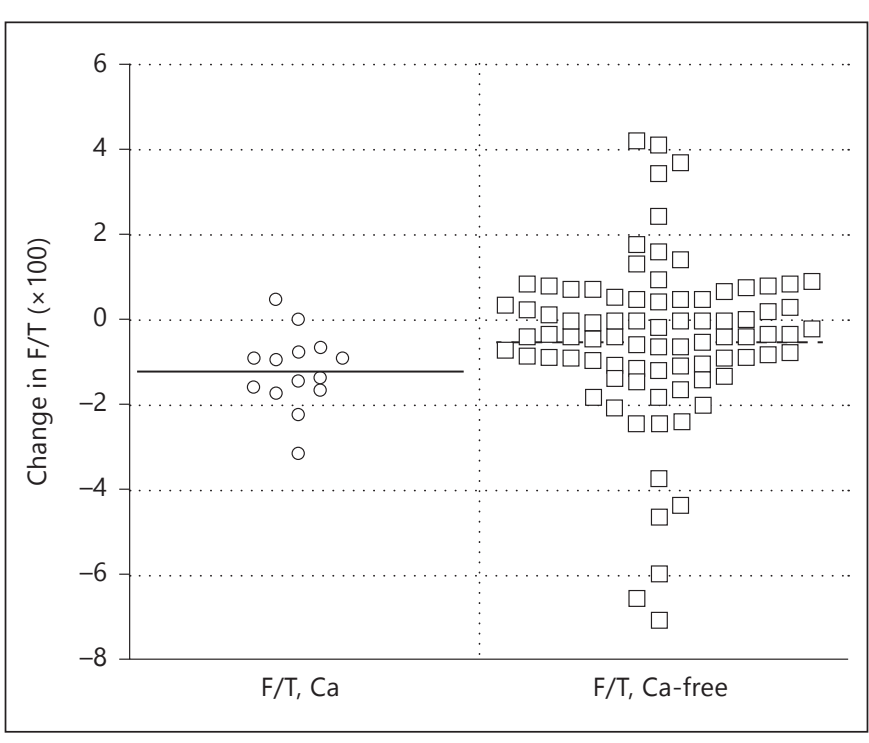

Fig. 3. Change in F/T. $\mathrm{Ca}=$ Cancer group.

cancer group, all PSA doubling times were $<72$ months and all PSA velocities were $\geq 1 \mathrm{ng} / \mathrm{ml} /$ year over the observation period. However, the two groups had overlapping ranges of values, indicating that the presence of cancer in these cases could not be separately distinguished by PSA doubling time or PSA velocity.

The change in the rate of total PSA was greater than that of free PSA in cancer and cancer-free cases. Thus, change in $\mathrm{F} / \mathrm{T}$ over time included decreases, no change, and increases in 94,0 and $6 \%$ of cases in the cancer group and in 56, 25 and 19\% of cases in the cancer-free group, respectively (table 2; fig. 3). Most of the changes in F/T in the cancer cases were decreases, whereas those in the cancer-free group varied to be dispersed irregularly among the cases.

To determine whether PSA kinetics might be used to select a subgroup of cancer-free cases among the cases who underwent an negative repeat biopsy, the changes in total PSA and F/T were examined (table 3 ). Cases with a yearly change in total PSA of $<1 \mathrm{ng} / \mathrm{ml}$ and no decrease in F/T may not have cancerous tissues, so they might represent positively a cancer-free subgroup in the negative repeat biopsy population.

\section{Discussion}

Prostate cancer screening of the general population has been performed in European countries. In some studies, men without prostate cancer who had PSA values $<3 \mathrm{ng} / \mathrm{ml}$ showed a metastatic disease rate of $0.86 \%$ over 
a 12-year period following the initial examination $[7,8]$. In contrast, men with PSA values $>4 \mathrm{ng} / \mathrm{ml}$ and a negative biopsy might have an increased prevalence of advanced cancer later, making it necessary to plan their subsequent management. The interval between the initial and repeat biopsies is controversial, and the detection rate may be influenced by the length of this interval. Reports have described a repeat biopsy intervals of 6 weeks [9] to a few years after the initial biopsy [10-12]. Cancers that are detected by repeat biopsy are often smaller and less likely to be high-grade [13]. In the present study the interval between biopsies was set at mostly every 2 years, and several measurements of PSA were scheduled during the intervening period, based on reports of active surveillance [14]. Men who had a yearly PSA fluctuation of $<1 \mathrm{ng} / \mathrm{ml}$ and a stable $\mathrm{F} / \mathrm{T}$ (table 3 ) did not present with prostate cancer over the approximately 4-year period following the initial biopsy. These data indicated that the interval between biopsies for cases with stable conditions can be set at $>4$ years, unless an extraordinary change in the markers is observed. No advanced disease was detected in the cancer group during the study period.

To improve the cancer detection rate in repeat biopsies, the recommendation is to collect an increased number of cores up to saturation biopsy [15-17]. Since a limited number of cores might not decrease the chance of obtaining the small foci and it was desirable to avoid adverse effects, in the present study the biopsies were performed via the perineal route, collecting $\geq 12$ biopsy cores, depending on prostate volume [18]. The perineal route is advantageous compared to the rectal route because it reduces the likelihood of missing some foci [19]. All methods of repeat biopsy, however, show similar detection rates after a negative initial biopsy [20]. Transurethral prostate resection in men with high or increased PSA is used to manage a negative repeat biopsy [21].

Since the use of a single marker might not allow the detection of all cancer patients, the respective markers are discussed for their utility. Increased total PSA alone correlates with cancer detection rate, and total PSA is therefore a prominent marker $[22,23]$. As prostate volume influences PSA levels, prostate volume and its derivatives, including PSA density and PSA TZ density, facilitate separating cancerous tissues from normal tissues [24].

The PSA that is produced by prostate cancer cells appears to escape proteolytic processing, and as a result cancer cases exhibit a great amount of complex PSA in proportion to total PSA. Consequently prostate cancer cases have a lower $\mathrm{F} / \mathrm{T}$ when compared with cancer-free cases [25]. In approximately $20-30 \% \mathrm{~F} / \mathrm{T}$ allows the separation of cancerous and benign tissues $[9,26,27]$. A combination of F/T and PSA TZ density was chosen from several possible markers and demonstrated an increased detection rate [28]. In addition, family history, prostate volume and previous biopsy status are important factors for reducing unnecessary testing [29]. PSA-related markers can fluctuate, and even cases with a decreasing trend in PSA derivatives may have cancerous tissues [30]. Moreover, prostate infection alters PSA values [31-33].

The combined use of multiple predictive factors has been designed and nomograms for repeat biopsy were reported, including many weighted markers such as age, digital rectal examination, PSA, prostate volume, PSA density, PSA TZ density, F/T, family history and initial biopsy findings $[10,11,34,35]$. Using these nomograms, the accuracy of cancer detection was approximately 70 $80 \%$. In the present study, calculations with the reported nomograms did not completely separate cancer cases from cancer-free cases.

Radiological examinations, such as magnetic resonance imaging and positron emission tomography, have been introduced in the findings of cancer, but their use in the detection of small foci in prostate cancer is limited $[36,37]$.

Prostate markers that show specificity for identifying cancer have been investigated. During the maturation of PSA after biosynthesis, several isoforms are produced by splicing. The amount of one isoform, [-2]proPSA, was shown to be higher in cancer cases compared with controls, then it was assayed to support the findings of PSA values [38]. Prostate cancer antigen 3 in urine is a new marker that shows greater sensitivity than serum PSA values [39]. Additionally, TMPRSS2-ERG gene fusion is a prostate cancer-specific event and an assay for its measurement in urine has been developed [40], however all of the prostate cancerous tissues did not contain the fused DNA. These new markers are currently being examined in clinical trials.

Together with these results, the detection of prostate cancer with any markers at one time point may not clearly distinguish cancer cases, because each marker has ranges that overlap in cancer and cancer-free cases.

The growth rate of cancerous tissues is higher than that of benign tissues, therefore PSA velocity and doubling time have been considered in the detection of cancer [41]. The PSA velocity is reported as $0.4-0.7 \mathrm{ng} / \mathrm{ml} /$ year in cancer cases [42-44], although in another study it was not an independent predictor [45]. Similarly, the change in PSA from baseline was a distinguishing factor, and an annual $3 \%$ change was reported as a cut-off value [46]. PSA doubling time has been described as a useful marker for 
screening. A PSA doubling time of 3-5 years has been considered as a cut-off value for identifying stable condition [47-49]. Changes in $\mathrm{F} / \mathrm{T}$ over time were emphasized for the detection of cancer [50]. Although PSA doubling time and velocity showed potential to act as differentiating factors, the results obtained using PSA velocity-related values indicated that they cannot clearly identify cancer cases.

All cancer cases may not be detected using a one time point examination in men with a suspicion of cancer. Serial examinations over an extended time period may be advised for the management of cases with elevated PSA levels [51]. To avoid unnecessary repeat biopsies, candidates with negative biopsy results can be separated into two groups. The first group has stable disease, which is distinguished by the course of total PSA and the F/T, and they may be observed regularly over a specified time interval without early repeat prostate biopsy. The second group is followed according to the routine strategy including subsequent biopsy. In the future, the development and use of new biomarkers could reduce more the number of multiple repeat biopsies in men with a suspicion of prostate cancer.

\section{Conclusion}

The rate of change in total PSA over time after a negative biopsy differed from the change in free PSA, and consequently the F/T differed thereafter. The trend of changes in total PSA, free PSA and F/T varied constantly among cancer cases when compared with cancer-free cases. These observations might be useful for determining the subsequent management of cases after negative biopsy.

It is important to detect early prostate cancer and to avoid unnecessary repeat biopsies. Since the characteristics of men with negative initial prostate biopsies are unequally distributed, a group with stable disease may be separated and managed under surveillance with periodic examination of total PSA and F/T except early repeat prostate biopsy over a specified time period. Further development on cancer-specific markers is awaited.

\section{Disclosure Statement}

The authors declare no conflicts of interest.

\section{References}

1 Roehl KA, Antenor JAV, Catalona WJ: Serial biopsy results in prostate cancer screening study. J Urol 2002;167:2435-2439.

2 Zaytoun OM, Jones JS: Prostate cancer detection after a negative prostate biopsy: lessons learnt in the Cleveland Clinic experience. Int J Urol 2011;18:557-568.

- 3 Shimbo M, Tomioka S, Sasaki M, Shima T, Suzuki N, Murakami S, Nakatsu H, Shimazaki J: PSA doubling time as a predictive factor on repeat biopsy for detection of prostate cancer. Jpn J Clin Oncol 2009;39:727-731.

4 Bishara T, Ramnami DM, Epstein JI: Highgrade prostatic intraepithelial neoplasia on needle biopsy. Am J Surg Pathol 2004;28:629633.

5 Schlesinger C, Bostwick DG, Iczkowski KA: High-grade prostatic intraepithelial neoplasia and atypical small acinar proliferation. Am J Surg Pathol 2005;29:1201-1207.

6 Connolly D, Black A, Murray LJ, Napolitano G, Gavin A, Keane PF: Methods of calculating prostate-specific antigen velocity. Eur Urol 2007;52:1044-1050.

7 Schröder FH, Hugosson J, Roobol MJ, Tammela TL, Ciatto S, Nelen V, Kwiatkowski M, Lujan M, Lilja H, Zappa M, Denis LJ, Recker F, Berenguer A, Määttänen L, Bangma $\mathrm{CH}$, Aus G, Villers A, Rebillard X, van der Kwast T, Blijenberg BG, Moss SM, de Koning HJ,
Auvinen A; ERSPC Investigators: Screening and prostate-cancer mortality in a randomized European study. New Engl J Med 2009; 360:1320-1328.

-8 Schröder FH, Hugosson J, Carlsson S, Tammela T, Määttänen L, Auvinen A, Kwiatkowski M, Recker F, Roobol MJ: Screening for prostate cancer decreases the risk of developing metastatic disease: findings from the European Randomized Study of Screening for Prostate Cancer (ERSPC). Eur Urol 2012;62: 745-752.

-9 Djavan B, Zlotta A, Remzi M, Ghawidel K, Basharkhah A, Schulman CC, Marberger M: Optimal predictors of prostate cancer on repeat prostate biopsy: a prospective study of 1,051 men. J Urol 2000;163:11441149.

10 Lopez-Corona E, Ohori M, Scardino PT, Reuter VE, Gonen M, Kattan MW: A nomogram for predicting a positive repeat prostate biopsy in patients with a previous negative biopsy session. J Urol 2003;170:1184-1188.

-11 Yanke BV, Gonen M, Scardino PT, Kattan MW: Validation of a nomogram for predicting positive repeat biopsy for prostate cancer. J Urol 2005; 173:421-424.

12 Roobol MJ, van der Cruijsen IW, Schröder FH: No reason for immediate repeat sextant biopsy after negative initial sextant biopsy in men with PSA level of $4.0 \mathrm{ng} / \mathrm{ml}$ or greater (ERSPC, Rotterdam). Urology 2004;63:892899.

13 Tan N, Lane BR, Li J, Moussa AS, Soriano M, Jones JS: Prostate cancers diagnosed at repeat biopsy are smaller and less likely to be high grade. J Urol 2008;180:1325-1329.

14 Klotz L, Zhang L, Lam A, Nam R, Mamedov A, Loblaw A: Clinical results of long-term follow-up of a large, active surveillance cohort with localized prostatic cancer. J Clin Oncol 2010;28:126-131

15 Pepe P, Aragona F: Saturation prostate needle biopsy and prostate cancer detection at initial and repeat evaluation. Urology 2007;70: 1131-1135.

16 Kawakami S, Numao N, Okubo Y, Koga F, Yamamoto S, Saito K, Fujii Y, Yonese J, Masuda H, Kihara K, Fukui I: Development, validation, and head-to-head comparison of logistic regression-based nomograms and artificial neural network models predicting prostate cancer on initial extended biopsy. Eur Urol 2008;54:601-611.

17 Maccagnano C, Gallina A, Roscigno M, Raber M, Capitanio U, Sacca A, Pellucchi F, Suardi N, Abdollah F, Montorsi F, Rigatti P, Scattoni $\mathrm{V}$ : Prostate saturation biopsy following a first negative biopsy: state of the art. Urol Int 2012; 89:126-135. 
18 Cormio L, Scattoni V, Lorusso F, Perrone A, di Fino G, Selvaggio O, Sanguedolce F, Bufo P, Montorsi F, Carrieri G: Prostate cancer detection rates in different biopsy schemes. Which cores for which patients? World J Urol 2012, Epub ahead of print.

19 Dimmen M, Vlatkovic L, Hole KH, Nesland JM, Brennhovd B, Axcrona K: Transperineal prostate biopsy detects significant cancer in patients with elevated prostate-specific antigen (PSA) levels and previous negative transrectal biopsies. BJU Int 2011;110:E69-E75.

20 Nelson AW, Harvey RC, Parker RA, Kastner C, Doble A, Gnanapragasam VJ: Repeat prostate biopsy strategies after initial negative biopsy: meta-regression comparing cancer detection of transperineal, transrectal saturation and MRI guided biopsy. PLoS One 2013; 8:e57480.

-21 Ploussard G, Dubosq F, Boublil V, Allory Y, de la Taille A, Vordos D, Hoznek A, Abbou CC, Salomon L: Extensive biopsies and transurethral prostate resection in men with previous negative biopsies and high or increasing prostate specific antigen. J Urol 2009;182: 1342-1349.

22 Schröder F, Kattan MW: The comparability of models for predicting the risk of a positive prostate biopsy with prostate-specific antigen alone: a systematic review. Eur Urol 2008;54: 274-290.

23 Inman BA, Zhang J, Shah ND, Denton BT: An examination of the dynamic changes in prostate-specific antigen occurring in a population-based cohort of men over time. BJU Int 2012;110:375-381.

24 Roobol MJ, Steyerberg EW, Kranse R, Wolters $\mathrm{T}$, van den Bergh $\mathrm{RC}$, Bangma $\mathrm{CH}$, Schröder FH: A risk-based strategy improves prostate-specific antigen-driven detection of prostate cancer. Eur Urol 2010;57:79-85.

25 Lilja H: Significance of different molecular 37 forms of serum PSA. The free, noncomplexed form of PSA versus that complexed to alpha 1-antichymotrypsin. Urol Clin North Am 1993;20:681-686

-26 Fowler JE, Bigler SA, Miles D, Yalkut DA: Predictors of first repeat biopsy cancer detection with suspected local stage prostate cancer. J Urol 2000;163:813-818.

-27 Djavan B, Remzi M, Schulman CC, Marberger M, Zlotta AR: Repeat prostate biopsy: who, how and when? A review. Eur Urol 2002;42: 93-103.

$\longrightarrow 28$ Chun FKH, Briganti A, Graefen M, Porter C, Montorsi F, Haese A, Scattoni V, Borden L, Steuber T, Salonia A, Schlomm T, Latchemsetty K, Walz J, Kim J, Eichelberg C, Currlin E, Ahyai SA, Erbersdobler A, Valiquette L, Heinzer H, Rigatti P, Huland H, Karakiewicz PI: Development and external validation of an extended repeat biopsy nomogram. J Urol 2007;177:510-515.

29 Roobol MJ, Zhu X, Schröder FH, van Leenders GJ, van Schaik RH, Bangma CH, Steyerberg EW: A calculator for prostate cancer risk 4 years after an initially negative screen: find- ings from ERSPC Rotterdam. Eur Urol 2013; 63:627-633.

- 30 Vickers AJ, Savage C, O’Brien MF, Lilja H: Systemic review of pretreatment prostatespecific antigen velocity and doubling time as predictors for prostate cancer. J Clin Oncol 2009;27:398-403.

31 Celhay O, de la Taille A, Salomon L, Dore B, Irani J: Fluctuating prostate-specific antigen levels in patients with initial negative biopsy: should we be reassured? BJU Int 2007;99: 1028-1030.

32 Connolly D, Black A, Murray LJ, Nambirajan T, Keane PF, Gavin A: Repeating an abnormal prostate-specific antigen (PSA) level: how relevant is a decrease in PSA? Prostate Cancer Prostatic Dis 2009;12:47-51.

33 Dirim A, Tekin MI, Koyluoglu E, Oguzulgen AI, Peskircioglu L, Ozkardes H: Do changes in a high serum prostate-specific antigen level and the free/total prostate-specific antigen ratio after antibiotic treatment rule out biopsy and the suspicion of cancer? Urol Int 2009;82:266-269.

34 Benecchi L, Pieri AM, Melissari M, Potenzoni $\mathrm{M}$, Pastizzaro CD: A novel nomogram to predict the probability of prostate cancer on repeat biopsy. J Urol 2008;180:146-149.

35 Moussa AS, Jones JS, Yu C, Fareed K, Kattan MW: Development and validation of a nomogram for predicting a positive repeat prostate biopsy in patients with a previous negative biopsy session in the era of extended prostate sampling. BJU Int 2010;106:1309-1314.

-36 Stamatakis L, Siddiqui MM, Nix JW, Logan J, Rais-Bahrami S, Walton-Diaz A, Hoang AN, Vourganti S, Truong H, Shuch B, Parnes HL, Turkbey B, Choyke PL, Wood BJ, Simon RM, Pinto PA: Accuracy of multiparametric magnetic resonance imaging in confirming eligibility for active surveillance for men with prostate cancer. Cancer 2013;119:3359-3366.

7 Umbehr MH, Müntener M, Hany T, Sulser T, Bachmann LM: The role of 11C-choline and $18 \mathrm{~F}$-fluorocholine positron emission tomography (PET) and PET/CT in prostate cancer: a systematic review and meta-analysis. Eur Urol 2013;64:106-117.

38 Catalona WJ, Partin AW, Sanda MG, Wei JT, Klee GG, Bangma CH, Slawin KM, Marks LS, Loeb S, Broyles DL, Shin SS, Cruz AB, Chan DW, Sokoll LJ, Roberts WL, van Schaik RH, Mizrahi IA: A multicenter study of [-2]proprostate specific antigen combined with prostate specific antigen (PSA) in combination with PSA and free PSA and free PSA for prostate cancer detection in the 2.0 to $10.0 \mathrm{ng} / \mathrm{ml}$ PSA range. J Urol 2011;185:1650-1655.

39 Marks LS, Fradet Y, Deras IL, Blasé A, Mathis J, Aubin SM, Cancio AT, Desaulniers M, Ellis WJ, Rittenhouse H, Groskopf J: PCA3 molecular urine assay for prostate cancer in men undergoing repeat biopsy. Urology 2007;69:532-535.

-40 Leyten GH, Hessels D, Jannink SA, Smit FP, de Jong H, Cornel EB, de Reijke TM, Vergunst H, Kil P, Knipscheer BC, van Oort IM, Mulders PF, Hulsbergen-van de Kaa CA, Schalken JA: Prospective multicentre evaluation of
PCA3 and TMPRSS2-ERG gene fusions as diagnostic and prognostic urinary biomarkers for prostate cancer. Eur Urol 2012 DOI: 10.1016/j.eururo.2012.11.014.

41 Loeb S, Kettermann A, Ferrucci L, Landis P, Metter EJ, Carter HB: PSA doubling time versus PSA velocity to predict high-risk prostate cancer: data from the Baltimore Longitudinal Study of Aging. Eur Urol 2008;54:1073-1080.

42 Connolly D, Black A, Murray LJ, Nambirajan T, Keane PF, Gavin A: The utility of prostatespecific antigen velocity thresholds in clinical practice: a population-based analysis. BJU Int 2008;101:1507-1512.

43 Loeb S, Metter EJ, Kan D, Roehl KA, Catalona WJ: Prostate-specific antigen velocity (PSAV) risk count improves the specificity of screening for clinically significant prostate cancer. BJU Int 2012;109:508-512.

44 Punglia RS, Cullen J, McLeod DG, Chen Y, D'Amico AV: Prostate-specific antigen velocity and the detection of Gleason score 7 to 10 prostate cancer. Cancer 2007;110:1973-1978.

45 Wolters T, Roobol MJ, Bangma CH, Schröder $\mathrm{FH}$ : Is prostate-specific antigen velocity selective for clinically significant prostate cancer in screening? European Randomized Study of Screening for Prostate Cancer (Rotterdam). Eur Urol 2009;55:385-392.

46 Wallner LP, Frencher SK, Hsu JWY, Chao CR, Nichol MB, Loo RK, Jacobsen SJ: Changes in serum prostate-specific antigen levels and the identification of prostate cancer in a large managed care population. BJU Int 2013; 111:1245-1252.

47 Khatami A, Aus G, Damber JE, Lilja H, Lodding P, Hugosson J: PSA doubling time predicts the outcome after active surveillance in screening-detected prostate cancer: results from the European randomized study of screening for prostate cancer, Sweden section. Int J Cancer 2006;120:170-174.

48 Garzotto M, Park Y, Mongoue-Tchokote S, Bledsoe J, Peters L, Blank BH, Austin D, Beer TM, Mori M: Recursive partitioning for risk stratification in men undergoing repeat prostate biopsies. Cancer 2005;104:1911-1917.

49 Moreira DM, Gerber L, Thomas JA, Banez LL, McKeever MG, Freeland SJ: Association of prostate-specific antigen doubling time and cancer in men undergoing repeat prostate biopsy. Int J Urol 2012;19:741-747.

50 Ploussard G, Nicolaiew N, Marchand C, Terry S, Allory Y, Vacherot F, Abbou CC, Salomon L, de la Taille A: Risk of repeat biopsy and prostate cancer detection after an initial extended negative biopsy: longitudinal follow-up from a prospective trial. BJU Int 2013;111:988-996.

51 Auprich M, Augustin H, Budaus L, Kluth L, Mannweiler S, Shariat SF, Fisch M, Graefen M, Pummer K, Chun FKH: A comparative performance analysis of total prostate-specific antigen, percentage free prostate-specific antigen, prostate-specific antigen velocity and urinary prostate cancer gene 3 in the first, second and third repeat prostate biopsy. BJU Int 2011;109:1627-1635. 